\title{
SOLDIERFISHES FROM TANABE BAY AND ADJACENT REGIONS (Berycida : Holocentridae)
}

$\operatorname{AUTHOR(S):~}$

Araga, Chuichi

\section{CITATION:}

Araga, Chuichi. SOLDIERFISHES FROM TANABE BAY AND ADJACENT REGIONS (Berycida: Holocentridae). PUBLICATIONS OF THE SETO MARINE BIOLOGICAL LABORATORY 1964, 12(4): 307-321

\section{ISSUE DATE:}

1964-12-10

URL:

http://hdl.handle.net/2433/175369

RIGHT: 


\title{
SOLDIERFISHES FROM TANABE BAY AND ADJACENT REGIONS \\ (Berycida : Holocentridae) $^{1)}$
}

\author{
ChûIChI ARAGA
}

Seto Marine Biological Laboratory

With Plates XVIII-XX, 1 Table and 1 Text-figure

The soldierfishes referred to the family Holocentridae possessing characteristic features, such as deeply notched dorsal fins, well roughened bony scales, four anal spines and brilliant coloration, live about reefs or rocks in rather shallow water from the tropical to temperate regions of the world. Although the fishes of this group are rather dominant in southern waters of Japan along the Pacific, the taxonomic study of the Japanese soldierfishes does not seem satisfactory because they exhibit extensive intraspecific variations in coloration and even in body form.

As the first step of the revision of Japanese members of this group, the external features are preliminarily given herewith for eight species included four genera based on the samples taken from the southwestern coast of Wakayama Prefecture. Of these, Holotrachys lima (VALEnciennes) is reported for the first time from the waters around Japan, and three species, Ostichthys pilwaxii (SteIndAchner), Holocentrus ruber (FoRskÅ) and H. spinifer (FoRSKÅL) are newly added to the ichthyofauna of Wakayama Prefecture.

The specimens examined were mainly collected in the mouth of Tanabe Bay by means of several fishing gears (Text-figure 1 and Table 1), and some of them were reared in the exhibition tanks of our aquarium for one to several months.

Before going further, I with to express my hearty thanks to Mr. S. SAKaI of our laboratory for his kindness in offering me valuable samples and data. My sincere gratitude to Prof. H. Utinomi and Dr. T. Tokioka of our laboratory and Prof. K. Matsubara and Dr. A. Ochia of the Fisheries Institute of Kyoto University for their kindness in giving me valuable advices and in reading the manuscript.

1) Contributions from the Seto Marine Biological Laboratory, No. 427.

Publ, Seto Mar, Biol, Lab., XII (4), 1964, (Article 24) 


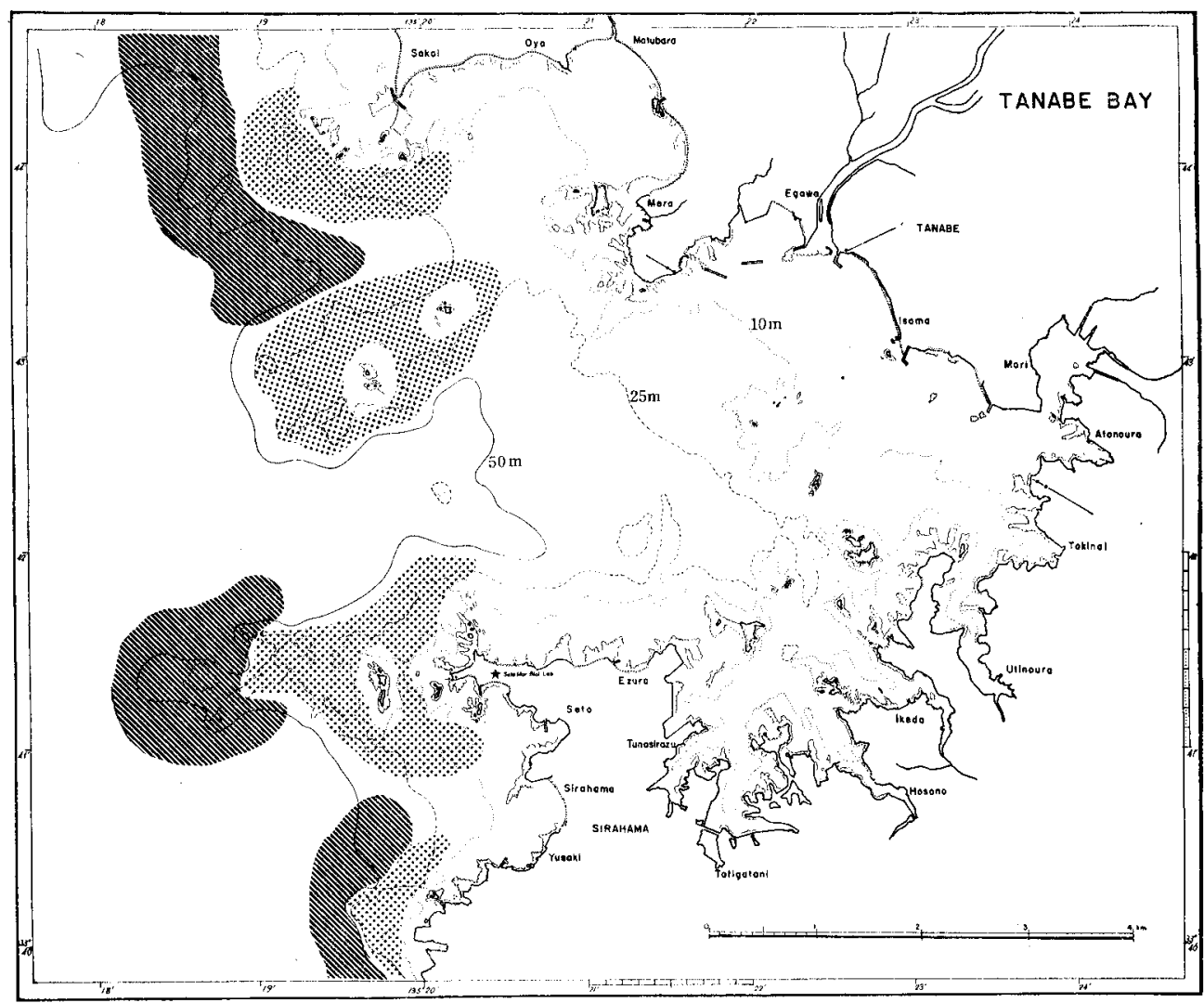

Text-figure 1. Fishing areas and gears by which the samples examined were obtained. The dotts show the area where trammel nets and shallow water long lines were used, and the lines show the area of deep water long line and hand line operations.

\section{Genus Holotrachys GÜNTHER}

\section{Holotrachys lima (VALENCIENNES) \\ (New Japanese name: Seto-ebisu) \\ (Plate XVIII, Above)}

Myripristis (Holotrachys) lima.-GÜNTHER 1874, p. 93-94, pl. LXIII, fig. A ; WEBER \& BEAUFORT 1929 , p. $252-253$

Holotrachys lima.-JENKINS 1903, p. 439 ; JORDAN \& EVERMANN 1905, p. 147, pl. IV ; JORDAN \& SEALE 1906, p. 365, fig. 25; WoODS 1953, p. 191-192. pl. 17, C.

Miterial examined. One specimen, $102 \mathrm{~mm}$ in standard length, off Yusaki, Nov uriber 27, 1962.

Description. Dorsal fin rays XII, 15 ; anal fin rays $I V, 12$; pectoral fin rays 
17 ; pelvic fin rays $I, 7$; branched caudal rays $9+9$; perforated scales on lateral line 39 , scales between lateral line and base of first dorsal spine 5 , those between lateral line and origin of anal fin 9 ; gill rakers on first arch $8+1+$ $13=22$.

Body depth 2.6 ; head length 2.7 ; both in standard length. Snout 6.3 ; eye diameter 3.2 ; interorbital space 6.3 ; depth of caudal peduncle 4.2 ; pectoral fin length 1.7; pelvic fin length 1.9; upper jaw 2.0; all in head length.

Body oblong, compressed; dorsal profile from tip of snout to base of spiny dorsal evenly arched; ventral profile of head nearly straight; mouth large, nearly horizontal; jaws equal, a knob at a median junction of mandible fitting into a depression developed on the tip of premaxillaries; nasal bones well developed, the anterior part slightly rests on upper lip; maxillary long, eminently enlarged posteriorly, extending backward beyond the rear margin of orbit; preopercle with numerous fine spinules marginally, but without a long spine at its angle, opercle also with a large number of spinules, upper three ones of which are more or less prolonged; scales on body small, extremely rough, each with long thin spines on its hind margin; dorsal spines short and heavy, fifth spine the longest, 3.2 times in head length; soft dorsal and anal, and pectoral fins rounded marginally; caudal fin rather slightly forked, lobes rounded posteriorly.

In life, head, upper part of body, and all fin rays deeply bright red; lower part of body paler than other with several longitudinal red lines, each of which is formed by darker edges of scales; spiny dorsal fin deep red as back of body, but membranes of soft dorsal, anal and posterior half of caudal fins pale pinkish; iris deep red.

In formalin, body grayish yellow with a purplish faint difused blotch on anterior part of its back, and with about ten yellowish bands along series of scales; all fins pale yellowish.

Remarks. This species is closely associated with Holotrachys riukiuensis FOWLER from the Riu Kiu Islands, but is separable from the latter in having the lower body, shorter head, shorter pectoral fin and fewer dorsal spines as suggested by Fowler (1946). Our specimen examined differs from Woods' specimens of $H$. lima from the Northern Marshall Islands, which are provided with indistinct golden or coppery blotches on some body areas, such as postorbital region, opercle and pectoral fin base. In this point, our specimen well resembles to the specimens respectively identified as $H$. lima by Günther, and Jordan and EvERMANN.

\section{Genus Ostichthys JORDAN \& EVERMANN}

Key to the species of Ostichthys from Tanabe Bay 
$\mathrm{a}^{1}$ Body high, depth about 2.2 in standard length; body uniformly deep bright red in life; caudal slightly concave O. japonicus

$\mathrm{a}^{2}$ Body low, depth about 2.5 in standard length; ground color of body bright red, with 9 intermittent longitudinal white bands, each of which is formed by a white blotch in the center of respective scale; caudal moderately forked o. pilwaxii

\section{Ostichthys japonicus (CUVIER \& VALENCIENNES)}

(Japanese name: Ebisu-dai)

(Plate XIX, A)

Ostichthys japonicus.-JoRDAN \& Fowler 1903, p. 11-12, fig. 2; OKADA \& MATSUBARA 1938, p. 139 ; KaMOHARA 1950 , p. 79 ; MATSUBARA 1955 , p. 443 , fig. 146 ; ABE 1963 , p. 70 , fig. 208 .

Material examined. Four specimens, 315 to $382 \mathrm{~mm}$ in standard length, off Seto, December 1961 to March 1963.

Description. Dorsal fin rays XI-I, 13 or 14 ; anal fin rays IV, 11 or 12 ; pectoral fin rays 16 or 17 ; pelvic fin rays $I, 7$; branched caudal rays $9+8$; pored scales on lateral line 28 , scales between lateral line and base of spinous dorsal fin 4 , those between lateral line and origin of anal fin $71 / 2$; gill rakers on first arch 7 or $8+1+12=20$ or 21 .

Body depth 2.1 to 2.3 ; head length 2.4 to 2.6 ; both in standard length. Snout 4.6 to 5.2 ; eye diameter 3.4 to 3.8 ; interorbital space 5.4 to 5.9 ; depth of caudal peduncle 4.1 to 4.5 ; pectoral fin length 1.7 to 2.2 ; upper jaw 1.5 to 1.8 ; all in head length.

Body oval, compressed; dorsal outline from tip of snout to origin of soft dorsal fin evenly convex, ventral outline from tip of mandible to origin of anal fin also loosly arched, but they are rather strongly curving to caudal peduncle posteriorly; head large and roughend; mouth very large, oblique; lower jaw somewhat prominent, a knob on its tip fitting in a large depression at the tip of snout; nasal bones developed, but its anterior tip never covering upper lip; maxillary long, extending posteriorly beyond the hind margin of eye; suplamaxillary very large, widely overlaped on maxillary; preopercle with fine serration marginally, without a long spine at its angle; opercle with numerous horizontal ridges on its surface and fine spinules marginally, upper one of which prolonged, enlarged and sometimes bicuspid; subopercle, interopercle and orbital bones also with fine serrations marginally; interorbital space rather broad, with two low ridges; nape with several radiating broad ridges, each surface very rugose; scales on body very large and firm, with short spines on their hind margin; dorsal spines long and heavy, third or 
fourth spine the longest, 2.3 to 2.6 times in head length; third anal spine the longest and strongest, 3.7 to 4.2 times in head length; soft dorsal and anal fins rounded distally; pectoral fin rounded; caudal fin slightly concave, lobes rounded posteriorly.

In life, head and body uniformly deep bright red; dorsal, basal part of caudal and pelvic fins red, but distal harf of caudal and anal somewhat paler than other; iris bright red.

In formalin, head and body reddish gray or pale yellowish; all fins pale yellowish or pinkish.

\section{Ostichthys pilwaxii (STEINDACHNER) \\ (Japanese name: Yase-ebisu) \\ (Plate XIX, B)}

Ostichthys pilwaxii.-JORDAN \& EVERMANN 1905, p. 147-148, fig. 52; JoRDAN \& SEALE 1906, p. 223 ; Okada \& Matsubara 1938, p. 139 ; Matsubara 1955, p. 443 ; Abe 1963, p. 71 , fig. 211 .

Material examined. Seven specimens, 210 to $270 \mathrm{~mm}$ in standard length, off Sakai, March 1960 to April 1964.

Description. Dorsal fin rays XII, 14 or 15 ; anal fin fays IV, 11 ; pectoral fin rays 14 or 15 ; pelvic fin rays $I, 7$; branched caudal rays $9+8$ or 9 ; pored scales on lateral line 28 or 29 , scales between lateral line and base of spinous dorsal fin 4, those between lateral line and origin of anal fin 7 ; gill rakers on first arch 6 or $7+1+11$ or $12=19$ or 20 .

Body depth 2.3 to 2.5 ; head length 2.5 to 2.7 ; both in standard length. Snout 3.9 to 4.8 ; eye diameter 3.6 to 4.1 ; interorbital space 6.5 to 7.9 ; depth of caudal peduncle 4.0 to 5.0 ; pectral fin length 1.8 to 2.3 ; pelvic fin length 2.4 to 2.7 ; upper jaw 1.8 to 2.1 ; all in head length.

Body oblong, well compressed; dorsal profile nearly straight on head, but loosely arched from nape to origin of soft dorsal, and then abruptly curving to caudal peduncle; head very large and rugose; mouth large, nearly horizontal; lower jaw somewhat prominent, its tip fitting in a deep depression in the upper jaw; nasal bones well developed, its anterior part covering anteriorly upper lip; maxillary long, extending posteriorly to the hind margin of eye; suplamaxillary very large, widely overlaped on maxillary; opercle, preopercle and orbital bones bear numerous fine spinules marginally, of which upper one of opercle prolonged, and sometimes bifurcate distally; interorbital space narrow, with 4 low ridges; nape roughened with several radiating ridges; scales on body very large and firm, with sharp, short spines on their hind margin; dorsal spines long and heavy, third spine the longest, 2.2 to 2.5 
times in head length; third anal spine the longest and strongest, 2.8 to 3.5 times in head length; soft dorsal and anal fins rounded marginally; pectoral fin somewhat pointed distally; caudal fin moderately forked, lobes rounded posteriorly.

In life, head deeply bright red, with 4 rows of white blotches on preopercle; ground colour of body also colored as same as the head, with 6 intermittent longitudinal white bands, which are formed by a large white blotch in the center of respective scale; dorsal, basal part of caudal, and middle part of pelvic fins deeply red as head, but pectoral, distal part of caudal, and anal pinkish; iris deeply red.

In formalin, head and body pale yellowish or somewhat pinkish, center of each scale yellow; all fins pale yellowish or pineish; lips pinkish ivory.

\section{Genus Myripristis CUvieR}

\section{Myripristis murdjan (FORSKÅL)}

\section{(Japanese name: Aka-matsukasa)}

(Plate XIX, C)

Myripristis murdjan.-GÜNTHER 1874, p. 92-93, pl. LXI; JENKINS 1903, p. 440; JORDAN \& Evermann 1905, p. 152-153, pl. V; Jordan \& SEALE 1906, p. 220 ; Weber \& BeauforT 1929, p. 259-262 ; AoYagi 1941, p. 469; Schultz 1943, p. 62 ; KAMOHARA 1952, p. 2 ; Woods 1953, p. 198, pl. 17, D; Matsubara 1955, p. 444 ; ABE 1963, p. 70, fig. 210.

Material examined. Two specimens, 100 and $168 \mathrm{~mm}$ in standard length, off Seto, August 1961; 1 specimen, $180 \mathrm{~mm}$, off Sakai, March 1962; 1 specimen, $133 \mathrm{~mm}$, off Yusaki, August 1964; 1 specimen, $150 \mathrm{~mm}$, off Seto, April 1963.

Description. Dorsal fin rays $\mathrm{X}-\mathrm{I}, 14$; anal fin rays $\mathrm{IV}, 12$; pectoral fin rays 15 ; pelvic fin rays $I, 7$; branched caudal rays $9+8$; perforated scales on lateral line 29 to 33 , scales between lateral line and base of spinous dorsal fin 3 , those between lateral line and base of anal fin 7; gill rakers on first arch 12 to $14+$ $1+22$ to $24=35$ to 39 .

Body depth 2.3 to 2.4 ; head length 2.8 to 3.2 ; both in standard length. Snout 5.0 to 6.0 ; eye diameter 2.1 to 2.7 ; interorbital space 3.5 to 4.6 ; depth of caudal peduncle 2.9 to 3.6 ; pectoral fin length 1.3 to 1.5 ; pelvic fin length 1.5 to 1.7 ; upper jaw 1.8 to 1.9 ; all in head length.

Body oblong, well compressed ; dorsal profile evenly arched on head, moderately curving to caudal peduncle posteriorly, ventral profile nearly straight anteriorly, well curved posteriorly along base of anal fin; eye very large; mouth rather large, oblique; jaws equal, a loose knob at the tip of lower jaw fitting into a slight depression of upper jaw ; nasal bones not well developed; maxillary long, eminently enlarged posteriorly, extending posteriorly 
beyond the rear margin of pupil; preopercle with fine serration marginally, but without a long spine at its angle, opercle, interopercle and orbital bones also with numerous fine spinules marginally, of which upper one of opercle prolonged; interorbital space rather broad, with two distinct ridges; nape with several radiating ridges; scales on body large, strongly ctenoid, each minutely serrated posteriorly; dorsal spines long and rather slender, third or fourth spine the longest, 2.0 to 2.6 times in head length; third anal spine the strongest, third and fourth ones about equal in length, 2.5 to 3.2 times in head length; soft dorsal and anal fins angular in shape; pectoral fin somewhat pointed distally; caudal fin moderately forked, robes rounded posteriorly.

In life, head and body carmine red; center of each scale paler than its margin ; opercular membrane and pectoral axil blackish ; dorsal spines pinkish, membranes of spinous dorsal pinkish basally, brick red distally; pelvic and anal spines pinkish white; anterior two rays of soft dorsal and anal white, next two or three raye reddish black distally; pectoral fin pinkish, paler distally; unbranched caudal rays white, branched caudal rays colored as same as body, of which outer two ones blackish distally; iris red.

In formalin, head and body pale reddish or yellowish, or whitish ; opercular flap and pectoral axil blackish; all fins pale yellowish except for blackish antero-distal tip of soft dorsal, anal and outer two branched caudal rays.

Remarks. One of our specimens differs in coloration from tipical $M$. mur djan, in having orange yellow fins without blackish markings. Since the present species exhibits extensive intraspecific variation in coloration, numerous specimens are needed to make out a perfect conclusion on its taxionomy, as pointed by Schultz (1943) and Woons (1953).

\section{Genus Holocentrus ScOPORI}

Key to the species of Holocentrus from Tanabe Bay

$a^{1}$ Scales on lateral line 36 in number.

$\mathrm{b}^{1}$ Body relatively low, depth about 2.5 in standard length; when alive, ground color of body bright red with 9 or 10 silvery white longitudinal bands; fins not tinged with black .H. spinosissimus

$\mathrm{b}^{2}$ Body relatively high, depth about 1.9 in standard length; ground color of body dark purplish red with 9 blackish longitudinal bands; pelvic and vertical fins with some black markings H. ruber

$a^{2}$ Scales on lateral line as same as or more than 42 .

$\mathrm{c}^{1}$ Scales on lateral line $42 ; 4$ rows of scales between spinous dorsal and lateral line; snout rather long, pointed; body and membranes of spinous dorsal deep red H. spinifer 
$c^{2} \quad$ Scales on lateral line 47 or $48 ; 3$ rows of scales between spinous dorsal and lateral line; snout short; membranes of spinous dorsal with a longitudinal white band near its base, body bright red with about 10 golden or silvery white longitudinal bands H. ittodai

\section{Holocentrus spinosissimus TEMMINCK \& SCHLEGEL}

\section{(Japanese name: Ittô-dai)}

(Plate XX, A)

Holocentrus spinosissimus.-Jordan \& Fowler 1903, p. 13-15, fig. 3; OKADA \& Matsubara 1938, p. 139 ; AOY AGI 1941, p. 469 ; Kamohara 1950, p. 78-79, fig. 69 ; Matsubara 1955, p. 444 ; ABE 1963, p. 70, fig. 208.

Material examined. Four specimens, 130 to $165 \mathrm{~mm}$ in standard length, off Seto, July 1963 to April 1964; 15 specimens 128 to $170 \mathrm{~mm}$, off Sakai, December 1961 to April 1964; 2 specimens, 146 and $150 \mathrm{~mm}$, off Yusaki, September 1962 and August 1964.

Description. Dorsal fin rays XI, 13 (rarely 12 ) ; anal fin rays IV, 9 ; pectoral fin rays 14 or 15 ; pelvic fin rays $I, 7$; branched caudal rays 9 or $8+8$; pored scales on lateral line 36 (rarely 37), scales between lateral line and base of first dorsal spine 3 , those between lateral line and origin of anal fin 7 ; gill rakers on first arch 6 or $7+1+9$ or $10=16$ to 18 .

Body depth 2.5 to 2.6 ; head length 2.6 to 3.1 ; both in standard length. Snout 4.5 to 5.5 ; eye diameter 2.4 to 2.9 ; interorbital space 3.9 to 4.7 ; depth of caudal peduncle 3.1 to 3.7 ; pectoral fin length 1.5 to 1.6 ; pelvic fin length 1.3 to 1.6 ; upper jaw 2.4 to 2.6 ; all in head length.

Body oblong, compressed; dorsal profile of head and ventral outline of body nearly straight, outline from nape to origin of soft dorsal loosely arched, but abruptly curving to caudal peduncle posteriorly; eye large, upper ridge of orbit slightly rising above interorbital space; mouth not large, nearly horizontal; jaws subequal, the upper slightly prominent; nasal bones developed its anterior tip reaching to upper lip; preorbital bone well enlarged, with a large triangular spine, resting on upper lip anteriorly; preopercle with a long, heavy spine at its angle, and with fine serrations marginally; opercle, interopercle and orbital bones also with numerous fine spinules marginally, of which upper two ones on opercle prolonged; scales on body relatively small, fairly rough; dorsal spines long and heavy, third spine the longest, 1.7 to 2.3 times in head length; third anal spine the longest and strongest, 1.5 to 1.8 times in head length; soft dorsal and anal fins angular in shape; pectoral fin rather pointed distally ; caudal fin moderately forked, robes rounded posteriorly.

In life, head deep bright red above, paler bellow, with a vertical white 
band on hind margin of preopercle; ground colour of body also deep bright red, with about 10 intermittent longitudinal white bands, each of which formed by a white blotch in the center of respective scale; dorsal spines pale pinkish, membranes of spinous dorsal deep brick red; pelvic and anal spines milky white; soft dorsal, pelvic and basal part of caudal fins also red; pectoral and distal part of caudal fins paler than other; lips pinkish white, iris bright red.

In formalin, head and body yellowith, center of each scale brownish yellow; base of pectoral fin whitish; all fins pale yellowish or somewhat pinkish.

\section{Holocentrus ruber (FORSKÅL) \\ (Japanese name: Ayame-ebisu) \\ (Plates XX, B)}

Holocentrum rubrum.-GÜNTHER 1874, p. 96 ; WEBER \& BEAUFORT 1929, p. 244-246.

Holocentrus alboruber.-JORDAN \& FOWLER 1903, p. 15-16.

Holocentrus ruber.-Jordan \& SEALE 1906, p. 225 ; Aoyagi 1941, p. 469 ; Schultz 1943, p. 67 ; Matsubara 1955, p. 444.

Material examined. One specimen, $195 \mathrm{~mm}$ in standard length, off Yusaki, November 1960.

Description. Dorsal fin rays XI, 13 ; anal fin rays $\mathrm{IV}, 15$; pectoral fin rays 14 ; pelvic fin rays $I, 7$; branched caudal rays $9+8$; pored scales on lateral line 36 , scales between lateral line and base of first dorsal spine 3 , those between lateral line and origin of anal fin 7 ; gill rakers on first arch $7+1+9=17$.

Body depth 2.5 ; head length 2.8 ; both in standard length. Snout 5.8 ; eye diameter 3.3 ; interorbital space 4.4 ; depth of caudal peduncle 3.3 ; pectoral fin length 1.6; pelvic fin length 1.7 ; upper jaw 2.7 ; all in head length.

Body oblong, compressed; dorsal profile of head convex above eyes, outline along base of spinous dorsal nearly streight, but abruptly curving to caudal peduncle posteriorly; mouth rather small, slightly oblique; jaws subequal, the upper somewhat prominent; nasal and preorbital bones eminently developed, resting on upper lip anteriorly; preopercle with a very long heavy spine on its angle, and with numerous fine spinules marginally; opercle, subopercle, interopercle and orbital bones also with fine serrations marginally, of which upper two ones on opercle enlarged and prolonged; scales on body rather rough; dorsal spines long and heavy, third spine the longest, 2.1 times in head length; third anal spine the longest and strongest, 1.8 times in head length; soft dorsal and anal fins pointed posteriorly; pectoral fin rounded distally; caudal fin moderately forked, robes rounded posteriorly.

In life, ground color of head and body dark purplish red, with a vertical white line on hind margin of preopercle and an indistinct vertical black band 
on anterior part of opercle, and with 9 blackish longitudinal bands on body ; spinous dorsal colored as same as body, all spines darker than membtanes; anterior two rays of soft dorsal, pelvic and anal fins dark red, somewhat paler than spinous dorsal fin.

In formalin, head and body brownish yellow, with a vertical black band on opercle, and with 9 longitudinal blackish band on body, of which lower 3 bands indistinct; dorsal spines dusky, membranes pale pinkinsh with blackish distal tips; black markings on soft dorsal, pelvic, anal and caudal fins somewhat indistinct in preserved specimen; pectoral and posterior part of other fins pale yellowish.

\section{Holocentrus spinifer (FORSKÅL) \\ (Japanese name: Togari-ebisu) \\ (Plate XVIII, below)}

Holocentrum spiniferum.-GÜNTHER 1874, p. 94-95; WEBER \& BEAUFORT 1929, p. 235-237.

Holocentrus leo.-JENKINS 1903, p. 441.

Holocentrus spinifer.-JoRdan \& EVERMANN 1905, p. 161, pl. VIII; JoRDAN \& SEALE 1906, p. 223 ; Schultz 1943, p. 68 ; Woods 1953, p. 218-220, pl. 20, A; Matsubara 1955, p. 444-445;

Holocentrus spiniferus.-AOYAGI 1941, p. 470, fig. 1.

Material examined. One specimen, $212 \mathrm{~mm}$ in standard length, off Yusaki, November 9, 1963.

Description. Dorsal fin rays $\mathrm{X}, 15$; anal fin rays $\mathrm{IV}, 10$; pectoral fin rays 15 ; pelvic fin rays $I, 7$; branched caudal rays $8+9$; pored scales on lateral line 42 , scales between lateral line and base of first dorsal spine 4 , those between lateral line and origin of anal fin 8 ; gill rakers on first arch $6+1+$ $11=18$.

Body depth 2.6 ; body width 5.6 ; head length 3.0 ; all in standard length. Snout 3.1 ; eye diameter 4.4 ; interorbital space 7.2 ; depth of caudal peduncle 3.4 ; pectoral fin length 1.6 ; pelvic fin length 1.7 ; upper jaw 2.8 ; all in standard length.

Body oval in shape, highly compressed; caudal peduncle long; dorsal profile slightly concave above eyes, strongly convex just before dorsal fin, ventral outline arched evenly anteriorly, abruptly curving to caudal peduncle posteriorly; head large, rather smooth; snout somewhat pointed; eye relatively small, upper ridge of orbit slightly rising above frontal bone; mouth rather small, oblique; jaws subequal, the lower slightly prominent; nasal bones developed, its anterior tip resting on upper lip anteriorly; preopercle with a very long spine on its angle, and with numerous fine spinules marginally; opercle, interopercle and orbital bones also with fine serrations marginally, 
of which upper two ones of opercle are enlarged flatly, posterior margin of subopercle entirely smooth; scales on body small, respectively smooth; dorsal spines very long, rather slender, third spine the longest, 2.1 times in head length; third anal spine the longest, 1.9 times in head length; soft dorsal and anal, and pectoral fins pointed posteriorly; caudal fin moderately forked, robes rounded posteriorly.

In life, body carmine red above, paler bellow, preopercle with a narrow white oblique band on its anterior part, and with a large, especially deep red blotch on its upper part; each scale on body with silvery white margin; pectoral axil and spinous dorsal fin deep red; lips and preopercular spine bright blood red; pelvic spine and anterior three spines of anal orangish or pinkish white; rest fins varied from dark orangish red to light reddish yellow; iris deep red with two black blotches just above and behind pupil.

In formalin, ground color of head and body light reddish yellow, back darker than breast and belly; body with about 12 intermittent longitudinal reddish brown bands, each of which formed by a dark blotch in the center of respective scale; preopercular spine and opercle somewhat dusky; posterior part of caudal peduncle and all fins yellowish; lips pinkish milky white.

Remarks. Our specimen examined differs a little in coloration from Aoy AGr's specimens of $H$. spiniferus from the Riu Kiu Islands, which have a dusky blotch on the back of caudal peduncle just behind soft dorsal fin. But in our specimen, distinctive blotch is not recognized on the caudal peduncle.

Woons (1953) described that young specimens of this species have two black spots on the spinous dorsal membrane.

\section{Holocectrus ittodai JORDAN \& FOWLER}

\section{(Japanese name: Teri-ebisu)}

(Plate XX, C)

Holocentrus ittodai.-JORDAN \& FowleR 1903, p. 16-17; OKADA \& MATSUBARA 1938, p. 140; MATSUBARA 1955, p. 445; ABE 1963, p. 71, fig. 212.

Holocentrus diadema.-KAMOHARA 1950, p. 79.

Material examined. Four specimens, 112 to $160 \mathrm{~mm}$ in standard length, off Sakai, February 1962 to April 1963;2 specimens, 119 and $135 \mathrm{~mm}$, off Seto March 1962.

Description. Dorsal fin rays XI, 13 ; anal fin rays IV, 9 ; pectoral fin rays 15 ; pelvic fin fays $I, 7$; branched caudal rays 9 or $10+8$; pored scales on lateral line 47 (raerly 48), scales between lateral line and base of first dorsal spine 3 , those between lateral line and origin of anal fin 7 ; gill rakers on first arch $6+1+12$ or $13=19$ or 20 . 
Body depth 2.8 to 3.1 ; head length 3.2 to 3.3 ; both in standard length. Snout 3.9 to 4.5 ; eye diameter 2.7 to 2.9 ; interorbital space 3.8 to 4.1 ; depth of caudal peduncle 3.5 to 3.9 ; pelvic fin length 1.4 to 1.6 ; upper jaw 2.7 to 2.9 ; all in head length.

Body relatively elongate, compressed; dorsal profile of head slightly convex above eyes, and slightly concave on nape; ventral outline of body nearly straight, exept for the posterior part along base of anal fin where it is abruptly curved to caudal peduncle; snout short; mouth small, nearly horizontal, jaws equal; nasal bones developed, extending anteriorly to upper lip; preorbital bone also developed, with a triangular spine on its anterior lower tip; preopercle with a long spine at its angle, and with fine serration marginally; opercle, subopercle, interopercle and orbital bones also with numerous fine spinules marginally, of which upper two ones of opercle are prolonged; scales of body small, not evidently rough; dorsal spines long and rather slender, fourth spine the longest, 1.7 to 2.0 times in head length; third anal spine the longest and very heavy, 1.3 to 1.5 times in head length; soft dorsal and anal fins more or less pointed; pectoral fin also somewhat pointed distally; caudal fin rather deeply forked, robes somewhat pointed posteriorly.

In, life, head deep blood red, with a vertical white band on hind margin of preopercle and with a oblique white band on cheek; body colored as same as head, with 3 golden longitudinal lines above lateral line and about 7 silvery white lengthwise bands below lateral line, belly paler than back; pectoral axil somewhat dusky; spinous dorsal membranes deep blood red, with a broad longitudinal white band near its base, and a large blackish blotch (sometimes indistinct) between first and third dorsal spines, distal tip of membrane white, spines paler than membranes; pelvic spine and anterior three spines of anal white; anterior harf of soft dorsal, first soft rays of pelvic, fourth spine of anal, and caudal fins deep red; rest of pelvic fin white; posterior half of soft dorsal, pectoral and rest of anal fins pale pinkish; lips and iris deep red.

In formalin, ground color of head and body reddish or brownish yellow; body with about 10 longitudinal whitish yellow bands formed by a spot on the center of respective scale. The band on lateral line scales paler than others and very distict. Each of scales on upper two or three rows of body sometimes with blackish margin; cheek pinkish white or dusky; lips pinkish or whitish yellow; pectoral axil with a large brownish black blotch; all fins pale yellowish; two blackish blotches on membranes between first three dorsal spines.

Remarks. Our specimens examined agree well with JORDAN and Fowlen's $H$. ittodai from the Riu Kiu Islands in coloration, and rather resemble to Woons' H. microstomus from the Marshal Islands in counts of fin rays and lateral line scales. Kaмона RA (1950) synonymized $H$. ittodai as a color variation 
with $H$. diadema.

\section{Some biological notes}

As seen in Text-figure 1 and Table 1 , most specimens examined here were collected with the trammel net, long line or hand line near the mouth of the Tanabe Bay at the depth of more than twenty meters. Although it has said that members of soldierfishes live in the shallow water or even in the tide-pools of the tropical areas, the fishes here reported have never been observed in the shallow waters less than fifteen meters, except for a single specimen.

Table 1. Number of individuals caught by respective fishing methods.

\begin{tabular}{|c|c|c|c|}
\hline species $\quad$ gears & trammel net & long line & hand line \\
\hline Holotrachys Lima & 1 & - & - \\
\hline Ostichthys japonicus & - & 4 & - \\
\hline o. $\quad$ pilwaxii & 6 & 1 & - \\
\hline Myripristis murdjan & 3 & - & 3 \\
\hline Holocentrus spinosissimus & 16 & 2 & 3 \\
\hline$H . \quad$ ruber & - & - & 1 \\
\hline spinifer & 1 & - & - \\
\hline H. $\quad$ ittodai & 6 & 一 & - \\
\hline
\end{tabular}

Trammel nets and long lines used here are set down at night for obtaining spiny lobsters or groupers and snappers. While, the catches of soldierfishes by hand lines, usually being operated in daytime, occur just after sunset or before sunrise.

It is interesting to note that $I$ have observed in daytime a single individual of Myripristis murdjan resting at the innermost part of a large cave at a depth of about seven meters. It was moving very slowly until the diver approached very near.

In the aquarium, the fishes newly reared in a tank used to hide themselves behind the rocks in daytime, but to swim actively at night af ter the light put out. Moreover, the small fishes kept in the same tank as a prey were usually eaten by soldierfishes at night.

All of above mentioned facts clearly show that the soldierfishes are nocturnal.

\section{REFERENCES}

ABE, S., 1963 : Genshoku Gyorui Kensaku Zukan. (Encyclopedia ichthyologica illustrated in colors with keys to the Japanese species) $v+36+358$ pp., 780 figs. Hokuryukan Co., Tokyo, (in Japanese) 
Aoy AGI, H., 1941 : The soldier-fishes, Holocentridae, found in the waters of the Riu-Kiu Islands. Zool. Mag., 53 (9), pp. 468-470, fig. 1.

1943 : Coral fishes. xii +224 pp., 54 figs., 37 pls. Maruzen Co., Tokyo.

FOWLER, H. W., 1946 : A Collection of fishes obtained in the Riu Kiu Islands by captain Ernest R. Tinkham A. U. S. Proc. Acad. Nat. Sci. Philadelphia, 48, pp. 123-218, figs. 1-76.

Gưnther, A., 1873-75: Andrew Garretr's Fishes der Südsee (I. Jour. Mus. Godeffroy, 2, pp. i-iv, 1-128, pls. 1-83.

Jenkins, E. K., 1903 : Report on collections of fishes made in the Hawaiian Islands, with descriptions of new species. Bull. U. S. Fish. Comm. XXII. pp. 417-511, figs. 1-50, pls. 1-4.

JordaN, D. S. \& H. W. Fowler, 1903: A review of the berycoid fishes of Japan. Proc. U. S. Nat. Mus., 26 (1306), pp. 1-21, figs. 1-4.

JORDAN, D. S. \& B. W. EVERMANN, 1905: The aquatic resourches of the Hawaiian Islands, part 1. The shore fishes. Bull. U. S. Fish. Comm., 23 (1) (1903), xxviii +574 pp. $65-73$ pls.

Jordan, D. S. \& A. SEAle, 1906 : The fishes of Samoa. Bull. U. S. Bur. Fish., 25, pp. 173455 , pls. $33-53$.

Jordan, E. K., 1925 : Notes on the fishes of Hawaii, with descriptions of six new species. Proc. U. S. Nat. Mus., 66 (2570), pp. 1-43, pls. 1-2.

Kamohara, T., 1950 : Description of the fishes from the provinces of Tosa and Kishu, Japan. 288 pp., 220 figs. Kochi-ken Bunkyo Kyokai, Kochi. (in Japanese)

, 1952: Addition to the fish fauna of Prov. Tosa, Japan. Rep. Kochi Univ., Nat. Sci., (2), pp. 1-10, figs. $1-3$.

MAtsubarA, K., 1955 : Fish morphology and hierarcy. part I. XII 790 pp., 289 figs. Ishizaki Shoten, Tokyo. (in Japanese)

Okada, Y. \& K. Matsubara, 1938 : Keys to the fishes and fish-like animals of Japan. XL + 584 pp., 113 pls. Sanseido Co., Tokyo. (in Japanese)

Schultz, L. P., 1943 : Fishes of the Phoenix and Samoan Islands collected in 1939 during the expedition of the U.S. S. "Bushnell". Bull. U. S. Nat. Mus., (180), pp. i-x, 1-316, figs. 1-27.

Schultz, L. P., E. S. Herald, E. A. Lachner, A. D. Welander and L. P. Woods, 1953 : Fishes of the Marshall and Marianas Islands Vol. 1. U. S. Nat. Mus. Bull. 202, pp. I-XXXII+ 1-685, figs. 1-90, pls. 1-74.

WeBer, M. \& L. F. de BeAufort, 1929: The fishes of the Indo-Australian Archipelago V. Anacanthini, Allotriognathi, Heterosomata, Berycomorphi, Percomorphi. xiv +458 pp., 98 figs. E. J. Brill Ltd., Leiden. 


\title{
EXPLANATION OF PLATES XVIII-XX
}

\author{
Plate XVIII
}

Above: Holotrachys lima (VAlenciennes), $98 \mathrm{~mm}$ in standard length.

Below : Holocentrus spinifer (FORSKÅL), $282 \mathrm{~mm}$ in standard length.

Plate XIX

A: Ostichthys japonicus (Cuvier \& Valenciennes), (after Jordan \& Fowler, 1903).

B : Ostichthys pilwaxii (STEINDACHNER), $196 \mathrm{~mm}$ in standard length.

C : Miripristis murdjan (FORSKÅL), $180 \mathrm{~mm}$ in standard length.

\section{Plate XX}

A : Holocentrus spinosissimus Temminck \& Schlegel, $170 \mathrm{~mm}$ in standard length.

B : Holocentrus ruber (FoRSKÅL), $195 \mathrm{~mm}$ in standard length.

C : Holocentrus ittodai JoRDAN \& Fowler, $149 \mathrm{~mm}$ in standard length.

(All photographs except for $O$. japanicus were taken by the author.) 

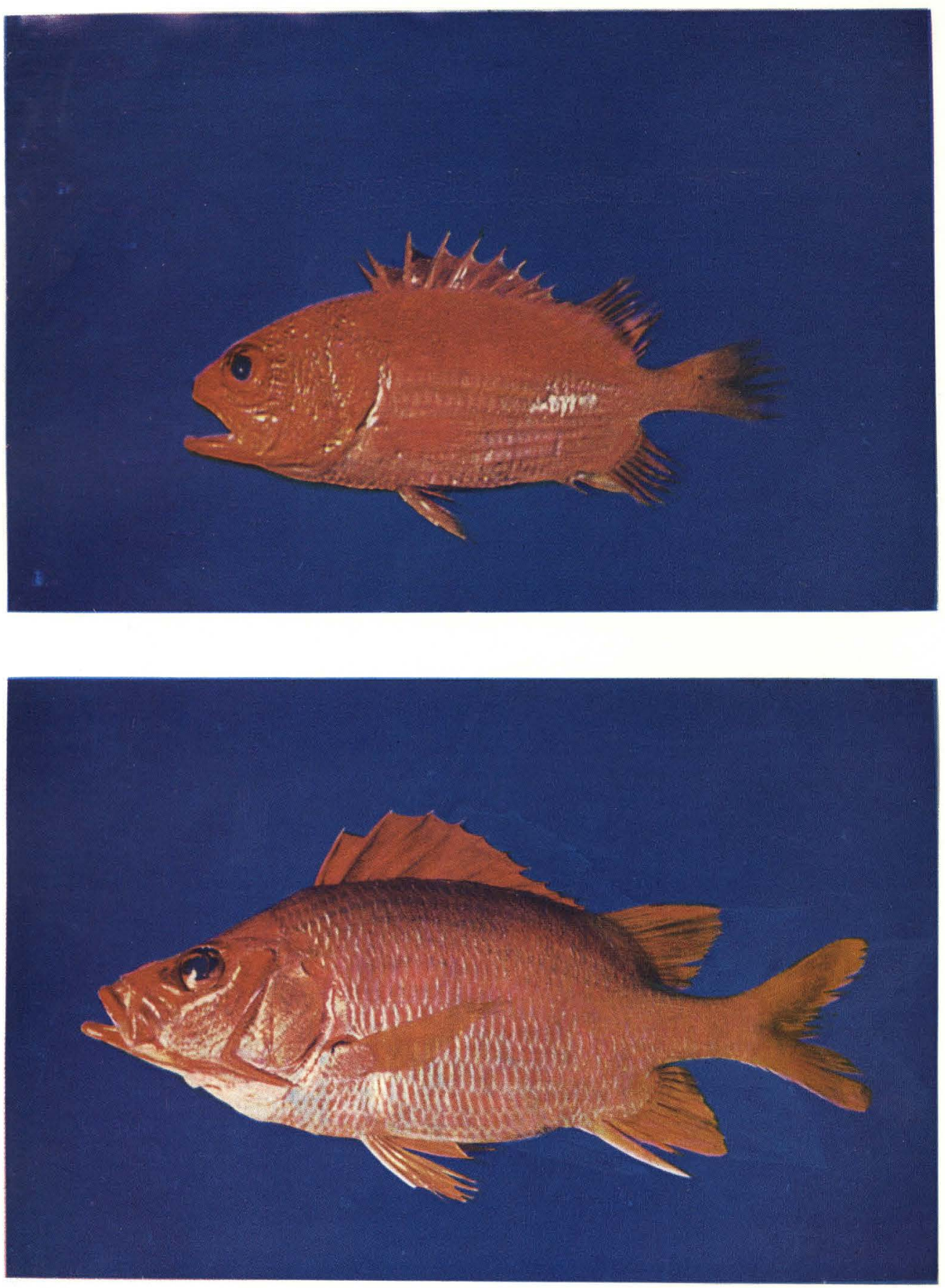

Ch. Araga: Soldjerfishes from Tanabe Bay. 
Publ. Seto Mar. Biol. Lab., XII, 4 (1964) PlATE XIX
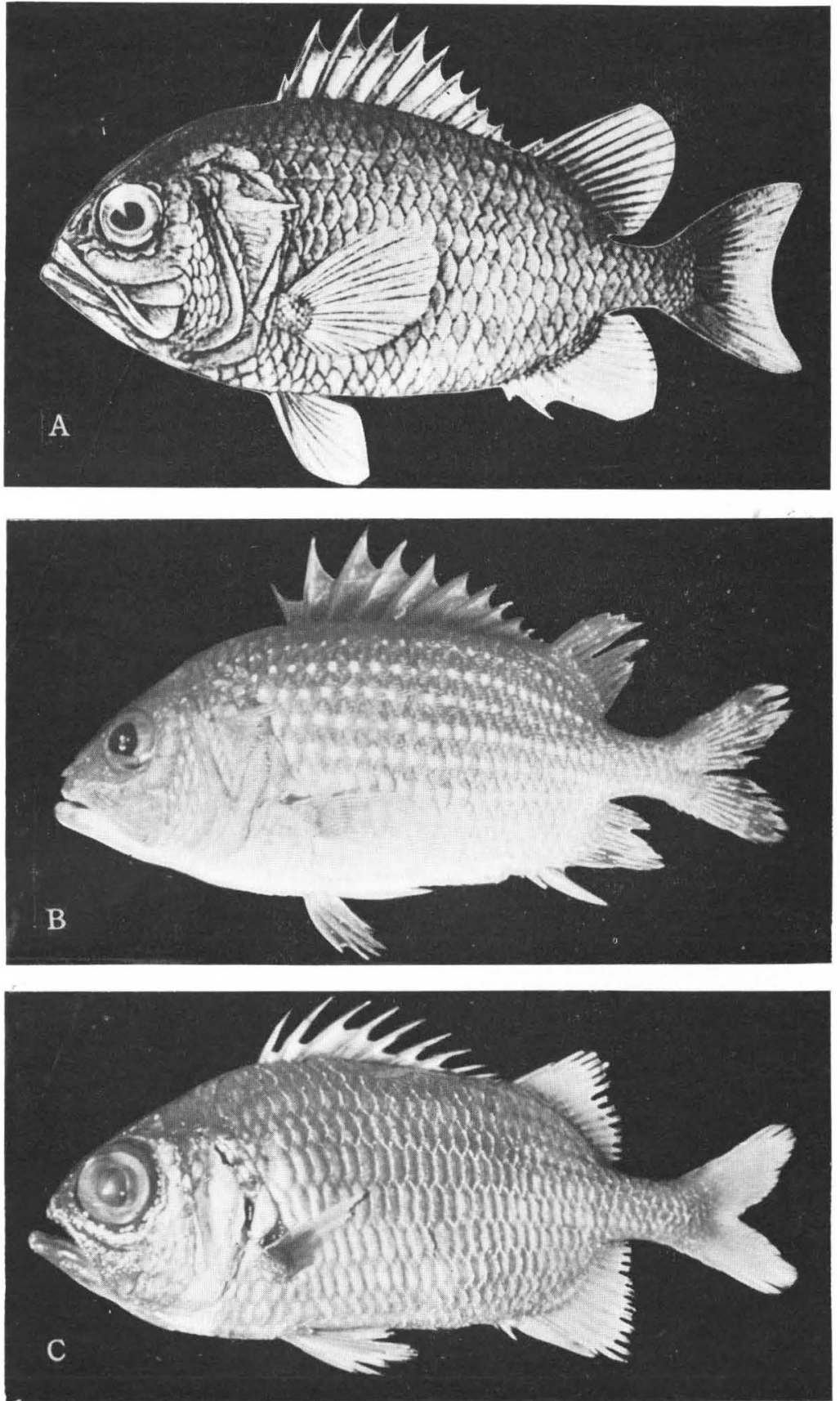

Ch. Araga: Soldierfishes from Tanabe Bay. 
Publ. Seto Mar. Biol. Lab., XII, 4 (1964) PlATE XX
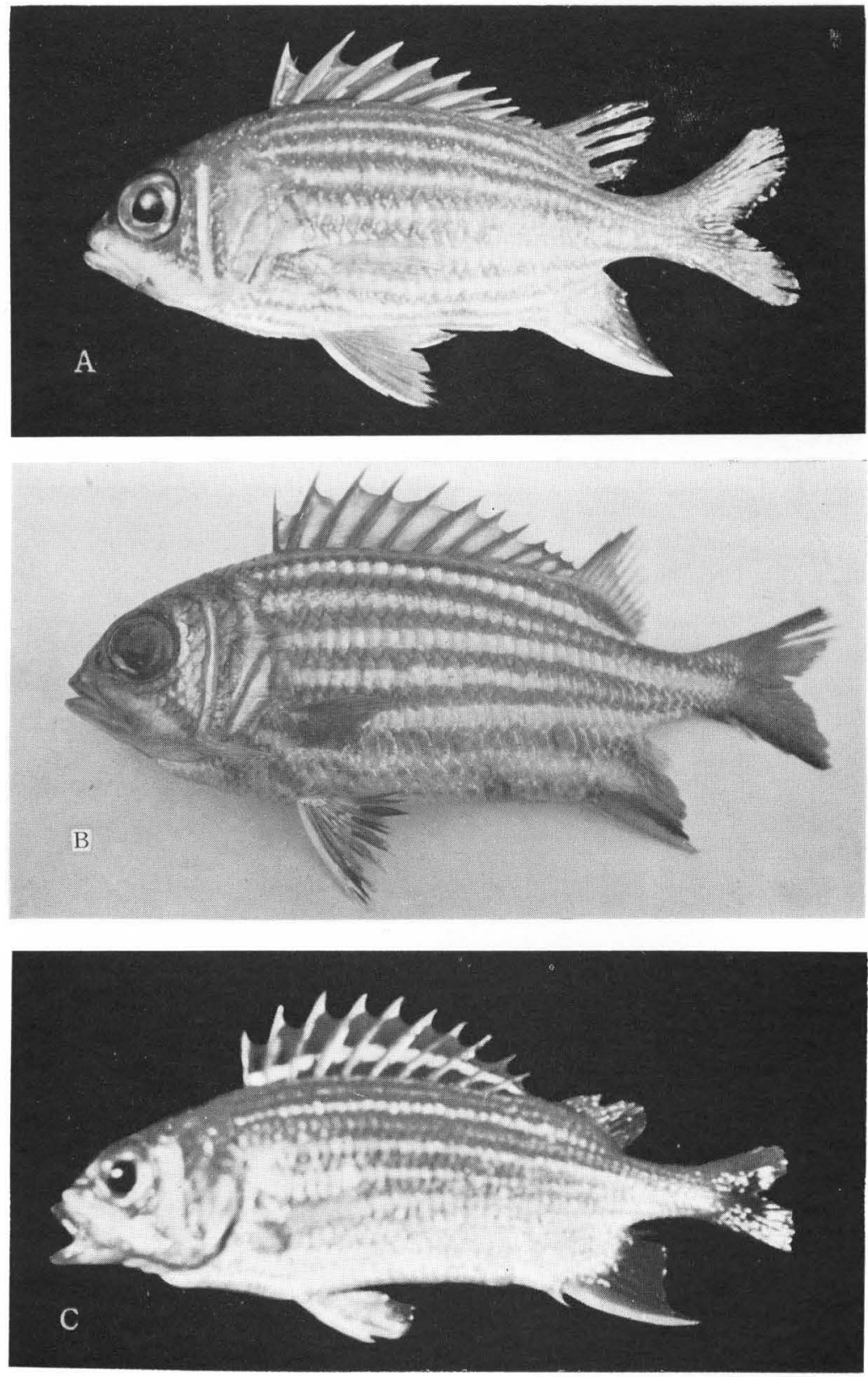

Ch. Araga: Soldierfishes from Tanabe Bay. 